\title{
Union Strategies of Addressing Conflicts at the
}

\section{National University of Lesotho}

\author{
Mamoeletsi Limakatso Mojalefa \\ Department of Business and Management Development \\ National University of Lesotho
}

Received: May 10, 2021 Accepted: May 18, 2021 Published: May 26, 2021

doi:10.5296/bms.v12i1.18617ＵRL: https://doi.org/10.5296/bms.v12i1.18617

\begin{abstract}
This paper discusses the strategies that are used by the unions to address industrial conflict at the National university of Lesotho (NUL). Content analysis was undertaken to understand the interviewee's responses and the NUL policy documents. The strategies are analyzed within the policy context, pre-industrial action, industrial action and post-industrial action. The study also shows that unions at the higher education institutions consult with other unions in the sector and, where other strategies have failed, they resort to either industrial action or legal process to resolve conflicts at the workplace. The findings further show that unions employ widespread communication between their members to share new development in the negotiation process. The findings reveal that strategies which unions normally adopt at NUL are: constant consultations and joint decision making, strikes/industrial action, work to rule, negotiations, collective bargaining, taking legal process and communication of possible ideas and solutions.
\end{abstract}

Keywords: strategies, conflict, unions, higher education institutions

\section{Introduction}

There are many mechanisms and strategies for resolving conflicts, some of which are complex while others are simple techniques. Lencioni (2005) asserts that the most important part of conflict resolution process is using the appropriate resolution for conflicts at hand. Lencioni (2005) also asserts that obstacles that are not related to the issues in contention are more difficult to resolve because issues have different and unrelated parameters.

From the interviews, a number of strategies used by unions in resolving the industrial conflicts emerged. Such strategies were identified as constant consultation and joint decision making, strikes/industrial actions, work to rule, negotiations, collective bargaining, legal processes and communications of possible ideas and solutions.

Biggs (1992) proposes the use of models that recognize that conflict-related factors interact 
with a mix of factors that may influence how a conflict should be resolved. Biggs (1992) lists some factors behind conflicts as personal differences, ethnic backgrounds, differences in understanding of policies and different leadership styles (also see Bampoh-Addo and Ansah-Koi, 2015).

\section{Literature Review}

The role of trade unions has changed from that of collective bargaining functions towards promoting voice and representation of the workers (Glennis, 2005). The resultant broad membership base which unions commanded strengthened their positions, giving them power to bargain and to derive successful outcomes BOPA (2002). The literature indicates that in America staff at public and private universities are unionized, but collective bargaining is more common at public universities. However, there are some states, including Georgia and North Carolina, which prohibit public employees from bargaining collectively. Unlike their counterparts in the west, traditional teacher unions in Africa are still in their infancy. For example, Teacher unions in South Africa only emerged in the late 1980s unlike those in other parts of the world, the South African unions focused mainly on the political struggle against apartheid. In Kenya, a trade union for post primary school teachers emerged as late as the 1990 's. The percentage of teachers in primary and secondary schools registered by the teacher unions is now about 80\% (Omolo and Odhong 2017). Trade union movement in Kenya is ran parallel to the struggle for independence, a process that was largely dominated by men and has engendered the perception that trade unionism is a masculine affair, hence many women have decided to shy away from active roles in union activities.

Forming synergies with NGOs to pursue specific goals of unions is another strategy. For example, in Kenya the Friedrich-Ebert-Stiftung works closely with trade unions, including the Central Organization of Trade Unions (COTU) to champion the labor rights. To increase women members' participation in trade union activities, the unions in Kenya have resorted to developing and initiating comprehensive capacity building and empowerment programs for women workers. Such programs target young women to enlighten them about worker and gender plights at work so that they can assert claims to their rights from employers and governments (Kaloki 2017). However, no such initiatives have been undertaken by the unions in Lesotho and where they have been undertaken, they have not been reported or empirically analyzed. Unions can strengthen themselves by increasing their membership and creating cohesion. For example, in Kenya, the KNPSWU initially experienced massive membership from 327 in 2011 to 45,000 in 2016 . The other common strategy that the unions employ is to create organizational flexibility and empowerment of members. The KNPSWU inherited a structure with multi branches that were formed, not according to membership drive, bat as a result of vested interests (Omollo and Odhong 2017).

Machingambi and Wades (2012) argue that leaders in higher education institutions should consider the circumstances of a conflict before deciding how best to resolve it. Musembi and Siele (2004) show that conflicts at universities are diverse and are caused by interaction of different issues. Hence, conflicts cannot be managed selective approaches; thorough diagnosis of the causes a prerequisite to an appropriate conflict resolution strategy (Fisher, 1993). Machingambi and Wades (2012) add that leaders at higher institutions of earning should be more proactive impulsive in handling conflicts at the workplace.

For example, at the Midlands State University in Oklahoma in the United States, the central administrator succeeded in resolving faculty conflict by introducing changes in the organizational structure of faculties in 2004. However, Machingambi and Wades (2012) warn 
that this same method may not work in the same faculty in a few years due to changing circumstances. Thus, Although Machingambi and Wades (2012) conclude that the Multi-Perspective Approach to conflict management at higher institutions of learning is the most preferred, educational administrators are at liberty to tinker with different models as situation or circumstances dictate. Currently there is a mounting theoretical battle on the best approach to apply in handling conflicts at educational institutions as there is no one system of action that has consistently worked and the experts still hold divergent views. A manager should not rush into prescribing resolutions to a conflict but should rather first seek to understand the underlying causes to the conflict (Machingambi and Wades, 2012).

\section{Methodology}

\subsection{Research Design}

Since the aim of this study was to explore the experiences and perceptions of the participants about unionism in higher education institutions, an exploratory research approach was adopted. Therefore it was assumed that the in-depth information obtained from participants would provide an understanding of strategic capabilities of union leaders in the higher education sector.

\subsection{Data Analysis}

The semi structured interviews were selected as the data collection method as this is the most appropriate instrument for a qualitative research. Face-to-face interviews with the groups of participants took place on the university premises, both at the Roma main campus and at the Maseru campus.

\section{Findings and Discussion}

\subsection{Constant Consultation and Joint Decision Making}

It appears that the unions adopt constant consultation and joint decision making as a strategy in resolving the conflict. The meetings of JCC and LUTARU, on one hand and JCC and NAWU, on the other hand, are documented and scheduled accordingly on the University almanac.

Employee participation is a process whereby the employees take part in and influence traditional management decisions that may affect them in the workplace. Participation can take place on various levels within the enterprise from the lowest supervisory level on the work floor to the highest management level.

According to Ehlers (2007) there are both direct and indirect approaches to participation. With direct worker participation, individual workers are given the "power" to participate directly in decisions in the workplace. An example of this would be teamwork approaches such as the quality circles. With indirect participation, the workers give their representatives (such as trade unions), the "power" to influence and take part in decisions that may affect them. Examples include participation through the structures such as workplace forums and bargaining councils. The intensity and scope of worker participation differ from organization to organization. The more power the workers have to influence decisions in the organization, the higher the degree of worker participation. 
There are four levels where participation can occur. Otto and Fourie (2016); Ehlers (2007) propose the following levels:

i) A low degree of participation will exist where workers are consulted or informed about certain decisions that being taken and where they are asked to give their views. These decisions are, however, often implemented irrespective of the views of the workers.

ii) Negotiation with workers is the second level of worker participation. This means that management is prepared to move according to the workers' input in the negotiation process. There is a situation of give and take, and it is accepted that the workers have the right and power to influence the final outcomes or decisions.

iii) Mutual decision-making with workers is a higher level of worker participation. It occurs where the workers and management share the responsibility for certain decisions in the workplace.

iv) The ultimate form of worker participation occurs when the workers make all the decisions. They basically manage the organization in that they elect their own managers. They have the right and the power to do so because they also own the enterprise.

From the above literature and from the findings of this study, it can be observed that the university structures are built in such a way that at the highest level of management some members of the Council are nominated by the employees. This registers well with level (iv) above. However, the University management does not allow the representatives to report the decisions of the Council to be reported to the respective constituencies.

Based on the literature and findings, it is evident that involving the employees in the decision-making process does not only empower the employees to contribute to the success of an organization but it also saves the institution some resources such as time and money through increased productivity and reduced outsourcing. The employees regard themselves as good assets of the organization and ultimately they feel motivated to go extra miles. Even the implementation of the University policies can become easy to execute because the employees feel that they own such policy decisions.

\subsection{Strikes/Industrial Action}

The study finds that when other strategies have failed, the employees adopt industrial action or a strike. The study further finds that before they go on a strike, the employees follow all the legal processes of embarking on a strike. The union leaders seek permission from the Commissioner of Labor and notify the University management of their plan. When permission is granted, they freely embark on a strike.

The Labor Relations Act (LRA) of 1995 defines a strike as the partial or complete concerted refusal to work, or the retardation or obstruction of work, by persons who are or have been employed by the same employer or by different employers, for the purpose of remedying a grievance or resolving a dispute in respect of any matter of mutual interest between the employer and employee; every reference to work in this definition includes overtime work, whether it is voluntary or compulsory. 


\subsection{Work To Rule}

The study reveals that the union leaders sometimes resort to work to rule as a strategy to resolve conflict at NUL.

According to Public Service Alliance of Canada (PSAC), Work to Rule means:

- $\quad$ Taking all of your scheduled coffee and lunch breaks.

- Not working any overtime of any kind for any reason.

- Not doing the work of a co-worker when they are absent from the office.

- Not performing any duties that aren't in your job description (we no longer have "other related duties" included in the job descriptions)

- $\quad$ Starting work at your scheduled time and not before; and stopping work at your scheduled time and not a minute later (that's considered free overtime for the employer).

Bendix (2005) considers Work-to-Rule as a popular action, especially among the employees who perform tasks on their own and who produce or do more than they are strictly required to do. Bendix (2005) further states that the strategy of work-to-rule leads to the employees adhering to the set hours of work and doing only what they are ordered to do or what they have to do in terms of their contracts of employment. Professional and skilled employees in particular can greatly affect the productivity or services of an organization by instituting an action of this nature.

\subsection{Negotiations}

Ehlers (2007) defines negotiation as a process through which two or more parties exchange goods or services and attempt to agree upon the exchange rate for them by making proposals that will satisfy the needs of the parties within the environment that influences the process. All the parties endeavor to secure maximum advantage for themselves during the process.

Some key concepts related to negotiation which need to be considered and appreciated by parties are:

- It is a process

- Two or more parties are involved

- Exchange occurs

- $\quad$ Agreement is sought

- Exchange rates are determined

- $\quad$ Proposals are made and considered

- Both parties aim at need satisfaction

- $\quad$ All parties have needs

- Environmental influences have an effect on agreements or outcomes

Based on the above concepts, it can be concluded that negotiation is the art of seeking an agreement to the maximum advantage of all concerned. 
Emphasis should therefore be placed on the seeking of agreement. This means that merely trying to bully someone into accepting your position is not negotiation. It is not effective either. We should not confuse the notion of seeking agreement with the notion of changing someone's mind. It is not necessary to do the latter to achieve the former.

The study finds that the unions apply negotiations as some of the strategies of trying to resolve industrial conflict between its members and employers. From the responses, it appears that the management of the University has never been interested in negotiations. These are normally initiated by the union leaders.

\subsection{Collective Bargaining}

Collective bargaining can be defined as a process whereby employers and organized groups of workers seek to reconcile their conflicting goals through mutual accommodation. The dynamic of collective bargaining is demand and concession. Its objective is agreement (Grogan: 2003). Unlike mere consultation, therefore, collective bargaining assumes willingness on both sides, not only to listen to and consider the representations of the other but also to abandon the set views, where possible, in order to facilitate a common ground.

Collective bargaining appeared in the early stages of the industrial revolution as a means of fixing the wages and other conditions of employment (Adair and Albertyn: 2000). The rationale for adopting collective bargaining for the workers was the replacement of unilateral decision making by the employer in relation to individual workers, thereby overcoming the weak bargaining position of the individual workers. Collective bargaining has, however, over the years of industrial development developed into a sophisticated means of transforming and regulating what occurs in the workplace (Adair and Albertyn, 2000).

On the other hand, International Labor Organization (ILO) (1960) views "collective bargaining as negotiations about the working conditions and terms of employment between an employer, a group of employers or one or more employers' organization, on the one hand, and one or more representative workers' organization on the other, with a view to reaching agreement".

The study has revealed that the unions also apply collective bargaining as a strategy to mitigate industrial conflict between the employees (union members) and the university management. However, from the responses, it was revealed that the university management is normally not concerned with bargaining with the unions.

The bargaining relationship is normally an employee or union-initiated relationship. It is believed that once the employees become aware of their labor rights, discriminatory practices, unfair labor practices or poor management practice of the employer, they often opt to join or form the unions which have more collective power and can represent the interests of the employees in the relationship with the employer. Both the LUTARU and NAWU leaders were of the opinion that when they approach the employer, it is with a view to claim organizational rights in terms of the Labor Code Order of 1992, and they might even make initial proposals regarding the formation or joining of a collective bargaining structure, changes to service conditions and employee rights. The study further concludes that the reason behind the establishment of JCC at the University is to sensitize the employees for a collective bargaining. 


\subsection{Taking Legal Process}

The findings of this study indicate that when the unions have exhausted all the strategies in resolving industrial conflict, they finally opt for legal processes as a way of establishing a long lasting solution to their dispute.

Employers and employees or the unions may decide among themselves on a procedure to be followed in the event of a dispute arising. Such procedures could specify the following:

- The manner in which a dispute is to be declared - This includes notice to the other party and a specification as to whether or not the declaration should be in writing.

- Time limits for replying to the allegations or claims of the first party.

- Arrangements for negotiation meetings to attempt settlement.

- Time limits for negotiation - A procedure may specify that, if negotiation does not result in settlement within a period of two weeks, the parties may take recourse to other measures.

- Other methods of dispute settlement, such as mediation or arbitration, which will be used by the parties.

- Whether a differentiation will be made between disputes of right and disputes of interest, and whether different settlement procedures will be used in each case.

- Whether or not there will be final recourse to the dispute settlement machinery established by the government or to legal action.

- Whether or not the right to a strike or a lockout is admitted and, if it is admitted (or legally allowed), the limitations set and safeguards provided. An employer may agree not to dismiss illegal strikes before a specified period has elapsed, or a union may undertake to remove illegally striking employees from the premises of the employer (Bendix, 2005).

\subsection{Communication of Possible Ideas and Solutions}

The study finds that union leaders and members from the two unions (LUTARU and NAWU) communicate possible ideas and solutions around a conflict as a way or strategy whenever there is industrial conflict between the employees and the employer. The study further finds that there is a time when the unions know well in advance that there is a looming strike among their members. In response, they propose a control mechanism. They approach the university management and communicate possible ideas and solutions before a strike can take place. The study finds that communication of possible ideas and solutions is one of the pre-industrial conflict solutions.

The study finds that during the strike, the unions sometimes delegate some of their members to act as the union representatives in the meetings between the management and the striking members. In doing so, the expectation is that those representatives should effectively communicate their ideas and possible solutions to the prevailing problems. The respondents shared their experiences on what happened during the long lasting strike of 2011/2012 academic year. They stated that communication was the only possible strategy to them at that time, given the situation. However, the participants highlighted that management did not listen to them. As a counter measure, the employer applied lock out and no-work -no pay strategies.

\section{Conclusions}

The study looked at the strategies that the unions in Lesotho use to tackle the problems that face the workers at higher education institutions of learning. It shows that some unions have previously 
employed solidarity and multi-stakeholder coalitions as a strategy to address their concerns in situations where a single union's voice is not adequate and where the trade union struggles with getting recognition from the employers. Some unions have chosen to work with the politicians. However, 50 unions aligned to the Basotho National Party, and which include unions in the education sector, have remained small and less effective than their rivals in representing their members. While some unions in Lesotho in other sectors have elected to work together with civil societies, such as the coming together of the prominent civil society organizations, the Lesotho Council of Non-Governmental Organization (LCN) and the Lesotho Congress of Trade Unions (COLETU), the main interest was to increase democratization in Lesotho and not necessarily to address the interests of the workers. Hence, the strategies of the unions that represent the workers at the higher institutions of learning are yet to be determined and studied empirically.

\section{References}

Adair, B., \& Albertyn, S. (2000). Collective Bargaining in the South African Public Sector - The Emergence of Sector Based Bargaining. Juta Publication.

Bampoh-Addo, H., \& Ansah-Koi, K. (2015). Conflict Resolution In Higher Education Institutions: The Case Of Ghanaian Public Universities. International Journal of Interdisciplinary Research Methods, 2(1), 53-70.

Bendix, S. (2005). Industrial Relations in South Africa ( $4^{\text {th }}$ Edition). Cape Town, Juta.

Biggs, J. B. (1992). A qualitative approach to grading students. herdsa news, 14(3), 3-6.

Elhers, L. (2007). Labour Relations Systems, Procedures and Practice. Pretoria. EAMS Publishing.

Fisher, R. (1993). Social Desirability Bias and the Validity of Indirect Questioning. Journal of Consumer Research, 20(2), 303-315. https://doi.org/10.1086/209351

Glennis, H. (2005). Right on the money: What do Australian unions think of performance-related pay? Journal of Employee Relations, 27(2), 141-159. https://doi.org/10.1108/01425450510572676

Grogan, J. (2003). Workplace Law. Juta Law.

Kaloki, T. (2017). Women Labour Empowerment through Trade Unions in Kenya. Retrieved from https://www.fes-connect.org/people/women-labour-empowerment-through-trade-unions-in-kenya

Lencioni, P. (2005). Overcoming the Five Dysfunctions of a Team: A Field Guide for Leaders, Managers, and Facilitators. Juaay Beaa Inc. ASIN: B004C7KWA0

Machingambi, S., \& Wades, N. (2012). Conflict management in tertiary education institutions. Journal of Social Science, 31(1), 63-69. https://doi.org/10.1080/09718923.2012.11893015

Musembi, O., \& Siele, S. (2004). Saitoti moves to probe unrest in schools. Daily Nation, July 19:1.

Omolo, J., \& Odhong, E. (2017). Trade Unions in Transformation Developing and Utilizing Power Resources: The Case of Kenya National Private Security Workers' Union. Berlin: Friedrich-Ebert-Stiftung. Global Policy and Development.

Otto, H., \& Fourie, L. M. (2016). Theorising participation as communicative action for development and social change Communicare. Journal for Communication Sciences in Southern Africa, 35(1), 20-39.

\section{Copyright}

Copyright for this article is retained by the author(s), with first publication rights granted to the journal.

This is an open-access article distributed under the terms and conditions of the Creative Commons Attribution license (http://creativecommons.org/licenses/by/4.0/). 